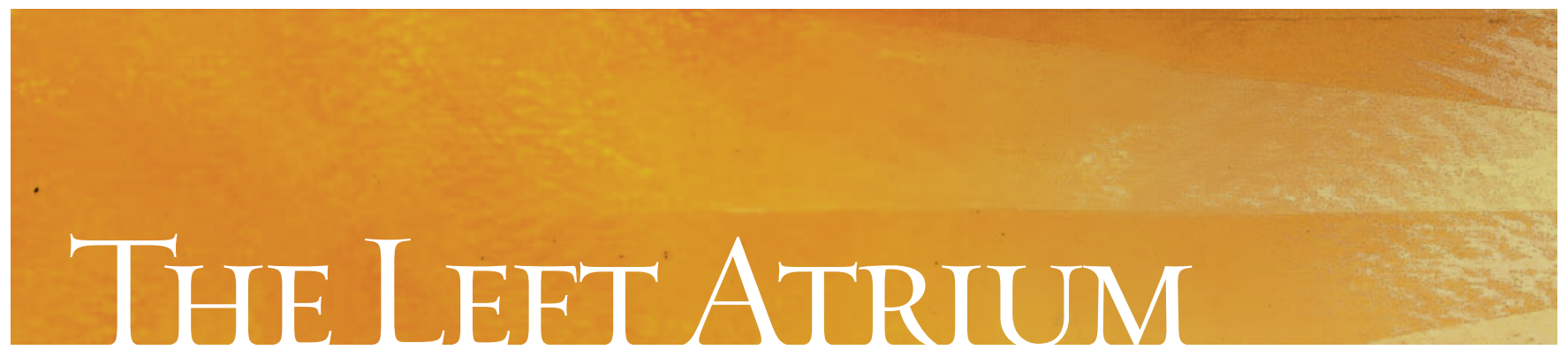

Book review

\title{
Profiling psychiatric research in Canada
}

Psyche in the lab:

celebrating brain science in Canada

Mary V. Seeman, Neil Seeman

Hogrefe \& Huber; 2006

258 pp \$37.45 ISBN o-88937-304-3

$\mathrm{E}$ verywhere you look in medicine these days, there are stories. Proponents of narrative medicine debate supporters of more traditional medical humanities. Medical students attend storytelling workshops and present "narratives" to an attentive audience. Storytelling is presumed to have benefits for those who tell the tale and those who listen (the potential risks seem to be less often considered). In addition to providing a means of conveying information, the process of storytelling has been imbued with a number of virtues, including the opportunity for better patient care and enhanced self-awareness. In the discussion of the therapeutic benefits of storytelling, one key fact is often overlooked: some stories are just more interesting than others.
(CPRF), this book contains 29 profiles of Canadians in the mental health field. Sixteen individuals profiled are researchers, while the remainder are consumers, philanthropists or other nonprofessionals. By telling the story of an institution through the narratives of people involved in its work, the authors add humanity to what could otherwise be a rather dry history.

The second half of the book is especially engaging. Voices of consumers and family members are well represented. Likewise, the stories of philanthropists and patrons provide interesting opportunities to learn about donors ranging from Joseph Tanenbaum, a generous supporter of Canadian charities, to Renée Claire Marier, a woman with schizophrenia who gives $50 \%$ of the profits from paintings she sells to schizophrenia research.

But as I read through the first section of Psyche in the Lab, featuring profiles of psychiatric researchers, I found that while some stories were especially interesting, others were rather unremarkable. The authors used "criterion-

... people who do fascinating research may lead lives that are, at least on the face of it, quite unexceptional.

This is apparent when reading Psyche in the Lab: Celebrating Brain Science in Canada, by Mary Seeman and Neil Seeman. Published to commemorate the 25th anniversary of the Canadian Psychiatric Research Foundation based techniques" to select " $\mathrm{I} 6$ leading scientists" for semistructured interviews. The intention was to choose a diverse group of accomplished scientists associated with the CPRF or the Canadian Institutes of Health Re-

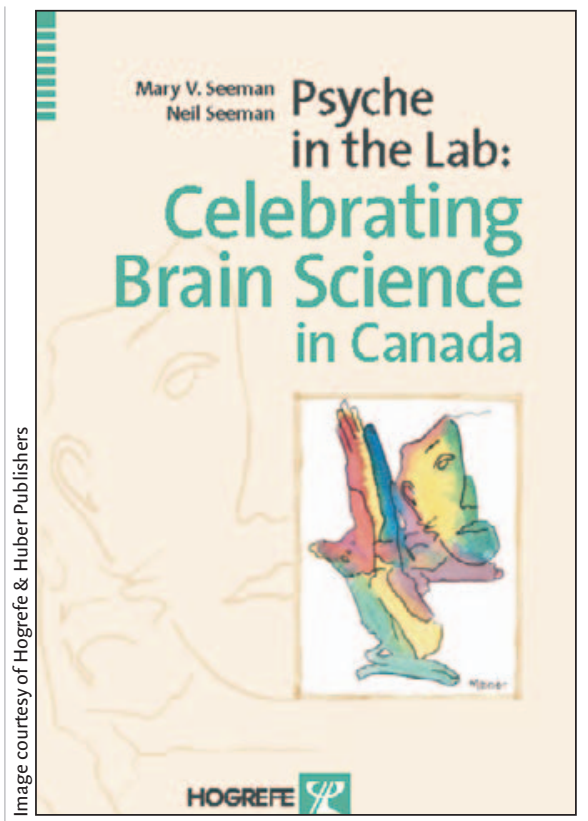

search. The interviews were conducted by an assistant, David Gentili, who also transcribed them.

In some cases, the person's research was interesting to me, while in others, it was the life story of the researcher. But I was struck by the fact that people who do fascinating research may lead lives that are, at least on the face of it, quite unexceptional. In contrast, the chapter on Bruno Cormier, a nowdeceased Québec psychiatrist who signed the "Refus global" in I 948 , made for engrossing reading not only because of his pioneering work in forensic psychiatry, but also because of his political activism.

Because the Canadian psychiatric community is relatively small, there were people profiled who I knew on a personal or professional level. While that stimulated my interest to read those chapters, the same obviously 
could not be said for the general reader.

Perhaps if the authors themselves had been able to interview the persons being profiled, the first part of the book might have been more engaging. Particular avenues of inquiry that stimulated the interest of the authors could have been explored, and then developed more fully. Several times I found myself wanting to know more about how the researcher felt at a critical juncture of his or her career. If the authors could have fleshed out the biographies with more detail, even tales that appeared to be quite ordinary might have revealed thought-provoking insights.

The greatest risk in telling the story of a research foundation is that it will be deathly dull. While the interest level may vary by chapter, Psyche in the Lab is, overall, a book that successfully integrates the experiences of several groups as it describes the history of an organization that has made an important contribution to mental health in Canada.

\section{Lara Hazelton}

Psychiatrist

Halifax, NS

\section{Creative convalescence}

I enjoy convalescence. It is the part that makes the illness worth while.

$$
\text { — George Bernard Shaw }
$$

Ignatius of Loyola, founder of the Jesuits, was converted to the religious life while recovering from a battle wound. Convalescence has been put to interesting use by many thinkers, artists and writers. Some, like Robert Louis Stevenson, became famous for it.

Tell us about recovery times yours, or your patients' - in The Left Atrium. We welcome prose submissions of up to 1000 words (pubs@cma.ca).

\section{Poem}

\section{doctors know}

some days are good

some days are bad

I have come to know

the bad days

remembrances

hung dry on the

crying eyes

daddy's dead

memories of the little girl

lost in the big strong arms

of her hero

her Atlas

who held her world up

now lets it down

gently on the snow

covered peaks

while I watch on

I can't say

why days are

good or bad

I can't say why

the sound of a soft voice

with a guitar makes

me choke up

a grown man

a hardened man

fighting

the same way he did

when he was seven

a man's man

an orthopaedic surgery resident

fighting

not to cry

not to let

the remembrances of humanity,

return

to my very own doctor eyes

\section{Doctors bleed}

Doctors cry

Doctors stand at the foot of your bed and pray to God they'll somehow see another day
Doctors die

inside

outside

Doctors have good days

secretly holding their child's

beautiful smile

in their minds

praying that God wouldn't

put her face

on the 6 year old female

the next patient

on the way

in transport from a car accident

her extracted dry blood

on loan to the

thirsty 401

Doctors know

inside

the smell of death

outside

the taste of regret

death

doctors know

good days

and

bad days

days

happy just to breathe the air

days spent

staring at the mirrored

liar

unspoken

silent

lost

Josh Mayich

Resident, orthopedic surgery

Kingston, Ont. 